\title{
Survey of potential sharpshooter and spittlebug vectors of Xylella fastidiosa to grapevines at the São Francisco River Valley, Brazil
}

\author{
Rudiney Ringenberg ${ }^{1}$, João Roberto Spotti Lopes², Cristiane Müller³, Wilson Sampaio de Azevedo-Filho ${ }^{4}$, \\ Beatriz Aguiar Jordão Paranhos ${ }^{5} \&$ Marcos Botton $^{6}$
}

\footnotetext{
${ }^{1}$ Centro Nacional de Pesquisa de Mandioca e Fruticultura, Empresa Brasileira de Pesquisa Agropecuária, Caixa Postal 007, 44380-000 Cruz das Almas-BA, Brasil. rudiney.ringenberg@embrapa.br

${ }^{2}$ Departamento de Entomologia e Acarologia, Universidade de São Paulo, Escola Superior de Agricultura Luiz de Queiroz, Caixa Postal 9 , 13418-900 Piracicaba-SP, Brasil. jrslopes@usp.br

${ }^{3}$ Departamento de Entomologia, Universidade de São Paulo, Escola Superior de Agricultura Luiz de Queiroz, Caixa Postal 9, 13418-900 Piracicaba-SP, Brasil. Bolsista Capes. muller2@dow.com

${ }^{4}$ Centro de Ciências Exatas, da Natureza e de Tecnologia, Campus Universitário da Região dos Vinhedos, Universidade de Caxias do Sul, Caixa Postal 32, 95700-000 Bento Gonçalves-RS, Brasil.wsafilho@ucs.br

${ }^{5}$ Centro de Pesquisa Agropecuária do Trópico Semi-árido, Empresa Brasileira de Pesquisa Agropecuária, Caixa Postal 23, $56302-970$ Petrolina-PE, Brasil. beatriz.paranhos@embrapa.br

${ }^{6}$ Centro Nacional de Pesquisa de Uva e Vinho, Empresa Brasileira de Pesquisa Agropecuária Caixa Postal 130, 95700-000 Bento Gonçalves-RS, Brasil.marcos.botton@embrapa.br
}

\begin{abstract}
Survey of potential sharpshooter and spittlebug vectors of Xylella fastidiosa to grapevines at the São Francisco River Valley, Brazil. Pierce's disease of grapevines, caused by Xylella fastidiosa, is a serious problem in some regions of North America, not yet reported in Brazil. In this study, a survey of potential sharpshooter (Hemiptera, Cicadellidae, Cicadellinae) and spittlebug (Hemiptera, Cercopidae) vectors of X. fastidiosa was conducted in vineyards at the São Francisco River Valley, a major grape growing region in Brazil. Four vineyards of Vitis vinifera L. were sampled fortnightly from June/2005 to June/2007, using yellow sticky cards, each placed at two different heights $(45 \mathrm{~cm}$ aboveground and $45 \mathrm{~cm}$ above the crop canopy) in 10 sampling localities. A total of 4,095 specimens of sharpshooters were collected, nearly all from 3 Proconiini species, Homalodisca spottii Takiya, Cavichioli \& McKamey, 2006 (96.8\% of the specimens), Tapajosa fulvopunctata (Signoret, 1854) (3.1\%), and Tretogonia cribrata Melichar, 1926 (1 specimen). Hortensia similis (Walker, 1851) (2 specimens) was the only Cicadellini species. Only 1 cercopid specimen, belonging to Aeneolamia colon (Germar, 1821), was trapped. Even though they are not considered potential Xylella vectors, 2 Gyponini leafhoppers were collected: Curtara samera DeLong \& Freytag, 1972 (11 specimens) and Curtara inflata DeLong \& Freytag, 1976 (1 specimen). Homalodisca spottii was observed feeding and mating on green branches of grapevines, in addition to egg masses. Because of its prevalence on the crop canopy, occurrence throughout the year (with peaks from February to August), and ability to colonize grapevines, $H$. spottii could be an important vector if a $X$. fastidiosa strain pathogenic to grapevines becomes introduced at the São Francisco River Valley.
\end{abstract}

KEYWORDS. Homalodisca spottii; Insecta; Pierce's disease; Vitis vinifera.

Grapes are one of the main fruit crops in Brazil, with a cultivated area of 82,580 ha (IBGE 2010). The São Francisco River Valley, located at the states of Bahia (BA) and Pernambuco (PE), is the major table grape producer region in the country. Grape production is privileged in this region due to climatic conditions and all-year-long harvesting periods (Araújo 2004).

Due to the large country size, lack of geographical barriers at borders with neighboring countries with agricultural tradition, and intense trade of plants through ports and airports, Brazilian viticulture may face problems with new exotic pests and pathogens. Vector-borne pathogens, in particular, pose a serious threat because some may be spread by indigenous or exotic vectors after introduction into a new region. Over the last decade, various grape leafroll-associated viruses have been reported to the states of Rio Grande do Sul (Fajardo et al. 2002) and São Paulo (Kuniyuki et al.
2008), and some of them are transmitted by mealybugs (Tsai et al. 2010). A phytoplasma grapevine yellows disease, whose local vector(s) is(are) still unknown, was detected in the states of São Paulo, Paraná, and Santa Catarina (Neroni et al. 2006). Another serious threat, not yet reported in Brazil, is Pierce's disease (PD), caused by the bacterium Xylella fastidiosa subsp. fastidiosa (Schaad et al. 2004), which is endemic to North and Central America, with great impact in California viticulture (Redak et al. 2004). A closely-related genotype of $X$. fastidiosa was recently reported causing PD in Taiwan (Su et al. 2013), showing the potential of this disease to become globally important.

The risk of PD emergence in Brazil and other South American countries exists, mainly by the introduction of infected propagative material from regions where the disease is endemic. Favorable climate, diversity, and abundance of host plants and competent vectors are some of the requirements for $X$. 
fastidiosa establishment in a newly-invaded area (Rathé et al. 2012). Xylella fastidiosa appears not to have major biotic or abiotic constraints in Brazil, because other genotypes of this bacterium already cause other economically important diseases such as Citrus variegated chlorosis (CVC) (Lee et al. 1993), Plum leaf scald (PLS) (French \& Kitajima 1978), and Coffee leaf scorch (Paradela Filho et al. 1997; Lima et al. 1998).

Considering the diversity of $X$. fastidiosa genotypes already present in Brazil (Almeida et al. 2008), there is also the possibility of natural infection of grapevines by $X$. fastidiosa from other host plants, mediated by insect vectors. Li et al. (2001) reported that a X. fastidiosa isolate from citrus with CVC was able to colonize and cause PD-like symptoms in grapevines after mechanical inoculation in the greenhouse. However, PD has not been observed at vineyards of São Paulo State where CVC is already established for more than 20 years (J.R.S. Lopes, pers. obs.).

Xylella fastidiosa is a xylem-limited bacterium transmitted by sharpshooter leafhoppers (Hemiptera, Cicadellidae, Cicadellinae) and spittlebugs (Hemiptera, Cercopidae) that feed from this plant tissue (Redak et al. 2004). In California, USA, where Pierce's disease is endemic, as many as 15 Cicadellinae and 5 Cercopidae species have been reported as vectors of this pathogen (Severin 1950; Purcell et al. 1979; Purcell 1980), but just a few of them, e.g. . Homalodisca vitripennis (Germar, 1821), Graphocephala atropunctata (Signoret, 1854) and Draeculacephala minerva Ball, 1927, are important for disease spread because of their prevalence at vineyards of that region and/or high transmission efficiency (Redak et al. 2004).

Various studies in southern and southeastern Brazil have revealed a large diversity of sharpshooter species occurring in orchards of plum (Hickel et al. 2001; Lopes et al. 2008), citrus (Yamamoto \& Gravena 2000; Ott et al. 2006), coffee (Giustolin et al. 2009), and grape (Ringenberg et al. 2010), and many of these species have already been identified as vectors of $X$. fastidiosa in citrus and coffee (Roberto et al. 1996; Krügner et al. 2000; Yamamoto et al. 2002; Marucci et al. 2008). However, there is no information on leafhopper or spittlebug species occurring in grapevine orchards in the region of the São Francisco River Valley, in northeastern Brazil, that could act as vectors of $X$. fastidiosa. The only survey of sharpshooter leafhoppers in northeastern Brazil was carried out in citrus orchards of Bahia State (Miranda et al. 2009), and indicated a different species composition when compared to surveys of orchards in southern Brazil.

The identification of potential vectors associated with grapevines in different growing regions is important to evaluate the risk of Pierce's disease spread in Brazilian viticulture and to establish adequate disease management strategies, in case of pathogen introduction. A first step to identifying vectors of $X$. fastidiosa is to analyze which leafhopper species or other xylem-feeding hoppers visit the crop. In this study, we investigated leafhopper and spittlebug species composition in vineyards of São Francisco River Valley, as well as, seasonal changes in populations of abundant sharpshooter species found.

\section{MATERIAL AND METHODS}

Experimental areas. Four Vitis vinifera L. commercial vineyards located at São Francisco River Valley, State of Pernambuco, were sampled for leafhoppers and cercopids: two with cv. Italy and two with cv. Rubi. The vineyards differed in planting age, distance from the São Francisco River and surrounding vegetation (Table I), but had similar cultivation characteristics (trellis system, drip irrigation) and same soil type.

Sampling by sticky traps. Ten sampling points were established per vineyard, spaced $40 \mathrm{~m}$ from each other. Two yellow sticky cards $(8.5$ x $11.5 \mathrm{~cm})$ (BioControle, São Paulo, SP, Brazil) were placed at each sampling point: one at $45 \mathrm{~cm}$ above the ground (low trap) and another at $45 \mathrm{~cm}$ above the crop canopy (high trap). The sticky traps were replaced every fifteen days from June/2005 to June/2007. Trapped leafhoppers and spittlebugs were identified and counted in the laboratory.

Visual observations. To identify leafhoppers or spittlebugs that use grape as host, visual inspections of insects on crop foliage and stems were carried only in area 3 (Table I). Evaluations were done at two different grape growth stages in August of 2006: 20 to 30 days after pruning (15 to $35-\mathrm{cm}$ long branches) and 31 to 40 days after pruning ( 35 to $55-\mathrm{cm}$ long branches). On each evaluation date, there were 40 replicates: 20 in the morning (between 9:00 and 11:00 a.m.) and 20 in the afternoon (between 3:00 and 5:00 p.m.); each replicate was made up by 2 -min observations. Leafhoppers found during inspections were captured and identified in the laboratory. The average number of leafhoppers observed per sample for each growth stage and time of the day, were compared by the Tukey test at 5\% probability using SAS 9.1.3 (SAS Institute 2003)

Species identification. Identification of specimens was carried out using dichotomous keys, descriptions, and redescriptions provided in the literature (Young 1968, 1977; Azevedo Filho \& Carvalho 2001; Takiya et al. 2006) and by direct comparison with specimens of entomological collections. Voucher specimens from each leafhopper and spittlebug species were deposited in the Entomological Collection at Embrapa Uva e Vinho (CEEUV) in Bento Gonçalves, RS, Brazil.

Populational fluctuation. Graphic analysis of populational variation over time in different areas was carried out only for species trapped in sufficient numbers. Graphics were built for each sampled vineyard (Areas 1-4) using the mean number of adults collected per trap and per 15-day period, separating data from the two sampling heights. Multiple regression analysis was carried out using the Statistica 7.1 software (STATSOFT INC. 2005), correlating the number of adults leafhoppers captured every 15 days (dependent variable) with climatic variables (average temperature and rainfall) registered for the month corresponding to the collection date or for the previous month (independent variables). Climatic data were obtained at the Agro-meteorological Station 1 of Bebedouro, PE, which is located half-way between Petrolina, PE, and Santa Maria da Boa Vista, PE. 
Table I. Location and characteristics of vineyards sampled with yellow sticky cards from June 2005 to June 2007 at São Francisco River Valley, State of Pernambuco (PE).

\begin{tabular}{|c|c|c|c|c|c|c|}
\hline Area & Location & $\begin{array}{c}\text { Age } \\
\text { (years) }\end{array}$ & $\begin{array}{c}\text { Grape } \\
\text { Cultivar }\end{array}$ & $\begin{array}{l}\text { Distance from } \\
\text { SFR }^{1}\end{array}$ & Surrounding vegetation & $\begin{array}{l}\text { Vineyard } \\
\text { size (ha) }\end{array}$ \\
\hline 1 & Petrolina, PE $9^{\circ} 16^{\prime} 00^{\prime \prime} \mathrm{S}, 40^{\circ} 25^{\prime} 00 \mathrm{~W}$ & 3 & Italy & $13 \mathrm{Km}$ & $\begin{array}{l}\text { Orchards of Mangifera indica L. (Anacardiaceae), Psidium sp. } \\
\text { (Myrtaceae), Malpighia punicifolia L. (Malpighiaceae), and grapevines }\end{array}$ & 2 \\
\hline 2 & Petrolina, PE $9^{\circ} 08^{\prime} 44^{\prime \prime} \mathrm{S}, 40^{\circ} 16^{\prime} 36^{\prime \prime} \mathrm{W}$ & 4 & Italy & $10 \mathrm{Km}$ & Native vegetation Caatinga & 3 \\
\hline 3 & $\begin{array}{l}\text { Santa Maria da Boa Vista, PE }{ }^{\circ} 01^{\prime} 41^{\prime \prime} \mathrm{S} \text {, } \\
39^{\circ} 56^{\prime} 55^{\prime \prime} \mathrm{W}\end{array}$ & 8 & Rubi & River margin & $\begin{array}{l}\text { Two borders with grapevines, and the others with riparian wood and } \\
\text { Caatinga }\end{array}$ & 2 \\
\hline 4 & $\begin{array}{l}\text { Santa Maria da Boa Vista, PE } 08^{\circ} 59^{\prime} 28^{\prime \prime} \text {, } \\
39^{\circ} 59^{\prime} 59^{\prime \prime} \mathrm{W}\end{array}$ & 4 & Rubi & $7 \mathrm{Km}$ & Three borders with grapevines and one with $\mathrm{M}$. indica & 1 \\
\hline
\end{tabular}

${ }^{1}$ Distance from São Francisco River (SFR).

\section{RESULTS AND DISCUSSION}

Leafhopper and spittlebug species composition. A total of 4,106 Cicadellidae specimens distributed in the subfamilies Cicadellinae $(4,094)$ and Iassinae (12) were collected in all vineyards by yellow sticky traps. In Cicadellinae (sharpshooter leafhoppers), most specimens were from the tribe Proconiini (4,092); only 2 individuals of Hortensia similis (Walker, 1851) (tribe Cicadellini) were trapped (Table II). Three Proconiini species were found and the most abundant was Homalodisca spottii Takiya, Cavichioli \& McKamey, 2006 with 3,965 specimens collected, followed by Tapajosa fulvopunctata (Signoret, 1854) (126 specimens), and Tretogonia cribrata Melichar, 1926 with a single individual (Table II). In Iassinae, for which no vector of $X$. fastidiosa has been reported, only two species of Gyponini, Curtara inflata DeLong \& Freytag, 1976 (1 specimen) and Curtara samera DeLong \& Freytag, 1972 (11 specimens) were trapped. A single individual of the cercopid species Aeneolamia colon was trapped (Table II).

Table II. Leafhopper and spittlebug species and number of specimens captured by yellow sticky traps from June 2005 to June 2007 in vineyards of Vitis vinifera at Petrolina (Areas 1 and 2) and Santa Maria da Boa Vista (Areas 3 and 4), southwest of Pernambuco State. Height of trap at $45 \mathrm{~cm}$ above the crop canopy $(\mathrm{H})$ and $45 \mathrm{~cm}$ above the ground (L).

\begin{tabular}{|c|c|c|c|c|c|c|c|c|c|}
\hline \multirow{3}{*}{ Family/Species } & \multicolumn{8}{|c|}{ Vineyards } & \multirow{3}{*}{ Total } \\
\hline & \multicolumn{2}{|c|}{ Area 1} & \multicolumn{2}{|c|}{ Area 2} & \multicolumn{2}{|c|}{ Area 3} & \multicolumn{2}{|c|}{ Area 4} & \\
\hline & $\mathrm{H}$ & $\mathrm{L}$ & $\mathrm{H}$ & $\mathrm{L}$ & $\mathrm{H}$ & $\mathrm{L}$ & $\mathrm{H}$ & $\mathrm{L}$ & \\
\hline \multicolumn{10}{|l|}{ Cicadellidae } \\
\hline Curtara inflata & 0 & 0 & 1 & 0 & 0 & 0 & 0 & 0 & 1 \\
\hline Curtara samera & 0 & 2 & 3 & 6 & 0 & 0 & 0 & 0 & 11 \\
\hline Homalodisca spottii & 201 & 35 & 746 & 88 & 1513 & 42 & 1258 & 82 & 3965 \\
\hline Hortensia similis & 0 & 0 & 0 & 0 & 0 & 2 & 0 & 0 & 2 \\
\hline Tapajosa fulvopunctata & 5 & 14 & 10 & 19 & 2 & 3 & 13 & 60 & 126 \\
\hline Tretogonia cribrata & 0 & 0 & 0 & 1 & 0 & 0 & 0 & 0 & 1 \\
\hline \multicolumn{10}{|l|}{ Cercopidae } \\
\hline Aeneolamia colon & 0 & 0 & 0 & 0 & 0 & 1 & 0 & 0 & 1 \\
\hline
\end{tabular}

Although a large number of sharpshooter specimens was captured in the present study (4,106 specimens), species diversity was low when compared with other surveys of sharpshooters in Brazil. Ringenberg et al. (2010) found 23 sharpshooter species in vineyards of the Serra Gaúcha region (Rio Grande do Sul State), in southern Brazil, and Lopes et al. (2008) found 24 species in plum orchards of the same region. In citrus orchards, Ott et al. (2006) reported nine species of Cicadellinae at Rio Grande do Sul State, whereas in the north coast of Bahia State, 11 species were found (Miranda et al. 2009).

The difference in number of species collected in these published surveys may be explained by the diversity of physiographic and climatic conditions of different regions in Brazil, indicating the need of studies on leafhopper composition for each region. The greater diversity of species in southern Brazil can be explained by the wet climate and variety of habitats and surrounding vegetation, which offers host plants for a larger number of species with different feeding habits and host preferences. In contrast, more selective environmental conditions and fewer host plants are available for leafhoppers in the São Francisco River Valley region, which has a semi-arid climate with low rainfall levels (annual average of $442.84 \mathrm{~mm}$ ) (Araújo 2004) at the Caatinga biome.

With intense limiting environmental factors, the number of individuals of common species tends to increase and rare ones to decrease (Silveira Neto et al. 1976). In fact, $H$. spottii was a prevalent leafhopper species in the vineyards at São Francisco River Valley, representing 96.8\% of the total catch of specimens. This sharpshooter species was first described from samples collected on citrus in states of Bahia and Sergipe (Takiya et al. 2006), and still had not been reported on grapevines. Based on a faunistic analysis, it was classified as a predominant leafhopper species in citrus orchards at the north coast of Bahia and appears to be well adapted to the northeastern Brazil, where it is considered a possible vector of the CVC strain of $X$. fastidiosa (Miranda et al. 2009). The second most trapped in the present study, $T$. fulvopunctata, was rare in citrus orchards of the northern coast of Bahia (Miranda et al. 2009).

Interestingly, only one specimen of Cercopidae (another group of potential vectors) was trapped by yellow sticky cards or observed on grapevines in this survey. These are contrasting results to a survey using similar trapping methods in vineyards of Rio Grande do Sul (Ringenberg et al. 2010), where 62 specimens belonging to six species in three genera (Deois, Notozulia, and Tunaima) of Cercopidae were collected. In that survey, most spittlebugs were collected by traps located $45 \mathrm{~cm}$ aboveground, suggesting that they were living on ground vegetation, which was fairly dense and composed primarily by Bidens pilosa L., Brachiaria plantaginea (Link), Cymbopogon sp., Lolium multiflorum Lam., Trifolium repens 
L., and Rumex sp. In contrast, the ground vegetation of the sampled vineyards in the present study was scarce and patchy (restricted to small areas near drip irrigation), comprised by Acanthospermum australe (Loefl), Bidens pilosa L., Cynodum dactylon (L.), Momordica charantia L., and Pennisetum spp. Besides vegetation, the semi-arid climate appears to be a key factor explaining the low diversity and abundance of cercopids in the vineyards of the São Francisco River Valley, because this group of insects is more adapted to moister climates, with higher rainfall levels and soil humidity (Silveira Neto et al. 1986).

Leafhopper distribution in relation to trap height and orchard location. Specimens of $H$. spottii were collected almost exclusively ( $94 \%$ of total catch) by high traps, whereas most $T$. fulvopunctata $(76 \%)$ and C. samera (73\%) specimens were captured by low traps (Table II). The few specimens of $H$. similis and T. cribrata were all captured in low traps. The trapping height indicates the flying height of the insect and its possible preference for the crop canopy or for the ground vegetation. In the present study, these data suggest that $H$. spottii has a flight activity concentrated on the grape canopy, while the other leafhopper species are more active on the ground vegetation of the vineyards. These results are consistent with those of Miranda et al. (2009), who observed a greater activity of $H$. spottii at the tree canopy and of $H$. similis on the weedy vegetation of citrus orchards.

Trap catches were not uniformly distributed among vineyards. From all $H$. spottii specimens collected, 39.2\% was collected in Area 3, 33.8\% in Area 4, 21.0\% in Area 2, and only $6.0 \%$ in Area 1 (Table II). Therefore, vineyards from Santa Maria da Boa Vista, PE (Areas 3 and 4) showed larger populations of $H$. spottii than those of Petrolina, PE (Areas 1 and 2). The higher numbers of $H$. spottii species collected in Area 3 may be due to the vineyard location adjacent to the riparian forest of the São Francisco River. It was previously reported that Proconiini sharpshooters are more abundant in coffee orchards near woody vegetation (Giustolin et al. 2009), possibly because of the higher diversity of plants that could serve as alternative hosts for these insects. A more favorable microclimatic condition (milder temperature, higher relative humidity) provided by the proximity to the river margin (Teixeira \& Silva 1999) and woody vegetation could also have influenced the higher trap catches in Area 3.

Visual observations of leafhoppers on grapevines. Homalodisca spottii was the only sharpshooter species found on grape plants. Mating couples, egg masses, and developing nymphs of $H$. spottii were observed on young branches, suggesting that grape is used as a host plant by this sharpshooter species, where feeding and reproduction takes place. Adults were commonly observed on stems and next to the last growth spurt, whereas nymphs were observed on leaves and stems of the last growth spurt and egg masses were found on the leaf abaxial surface (Fig. 1).

Visual inspections on the crop foliage and stems of 'Rubi' grapevines conducted at 20 to 30 post-pruning days (15- to 35-cm long branches) in Area 3 (Santa Maria da Boa Vista,
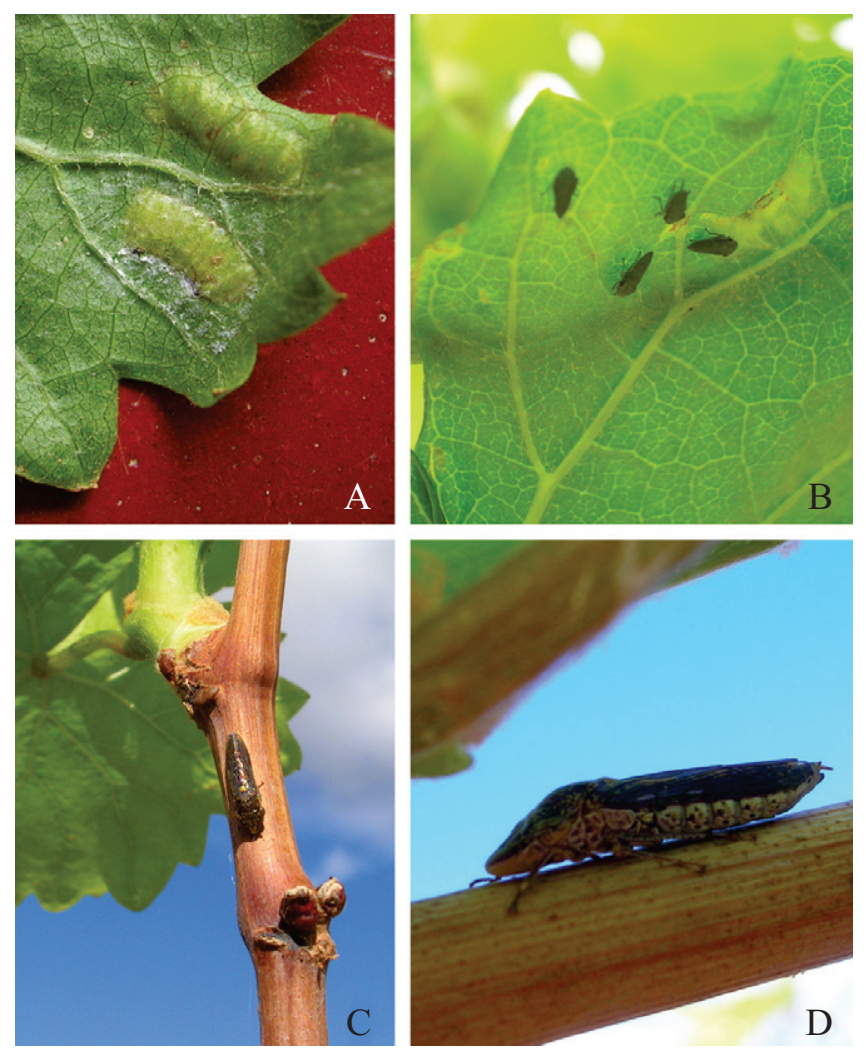

Fig. 1. Egg mass (A), nymphs (B), and adults (C e D) of the sharpshooter Homalodisca spottii observed on grapevines in Santa Maria da Boa Vista, PE, 14/08/2006. (Photo credits: João R. S. Lopes).

PE) indicated an average number of $1.95 \pm 0.18 \mathrm{H}$. spottii adults per sample (2-min observation) $(\mathrm{n}=20)$ during the morning (9:00-11:00 am), which was nearly twice the average of $1.1 \pm 0.18$ recorded during the afternoon (3:00-5:00 $\mathrm{pm})(\mathrm{P}<0.05)$. Interestingly, no difference in sharpshooter population was found between morning $(1.6 \pm 0.25)$ vs. afternoon $(1.6 \pm 0.22)(\mathrm{P}>0.05)$ when visual observations were carried out on older branches (35- to 55-cm long), at 31-40 days after pruning. We do not know the reason for the lower numbers of adults of $H$. spottii observed on younger branches (20-30 days after pruning) when sampling was done in the afternoon. We speculate that sharpshooter adults might seek shelter under more developed leaves and stems of older branches for protection against the higher temperatures in the afternoon. Nonetheless, this information is relevant for designing a sampling plan based on visual inspections, which should be done in the morning to allow more stable estimates of sharpshooter populations at different branch growth stages.

Populational fluctuation of adults of $H$. spottii. In the four grapevine areas studied, most population peaks of $H$. spottii occurred in the first semester (Fig 2). Areas 3 and 4 presented the highest mean numbers of captured individuals per trap, with major peaks in autumn and winter (May-August), but insects were collected during almost the entire sampling period. In Areas 1 and 2, major peaks were observed during summer and autumn (February-June), but there were long periods without capture, especially from August to December. 

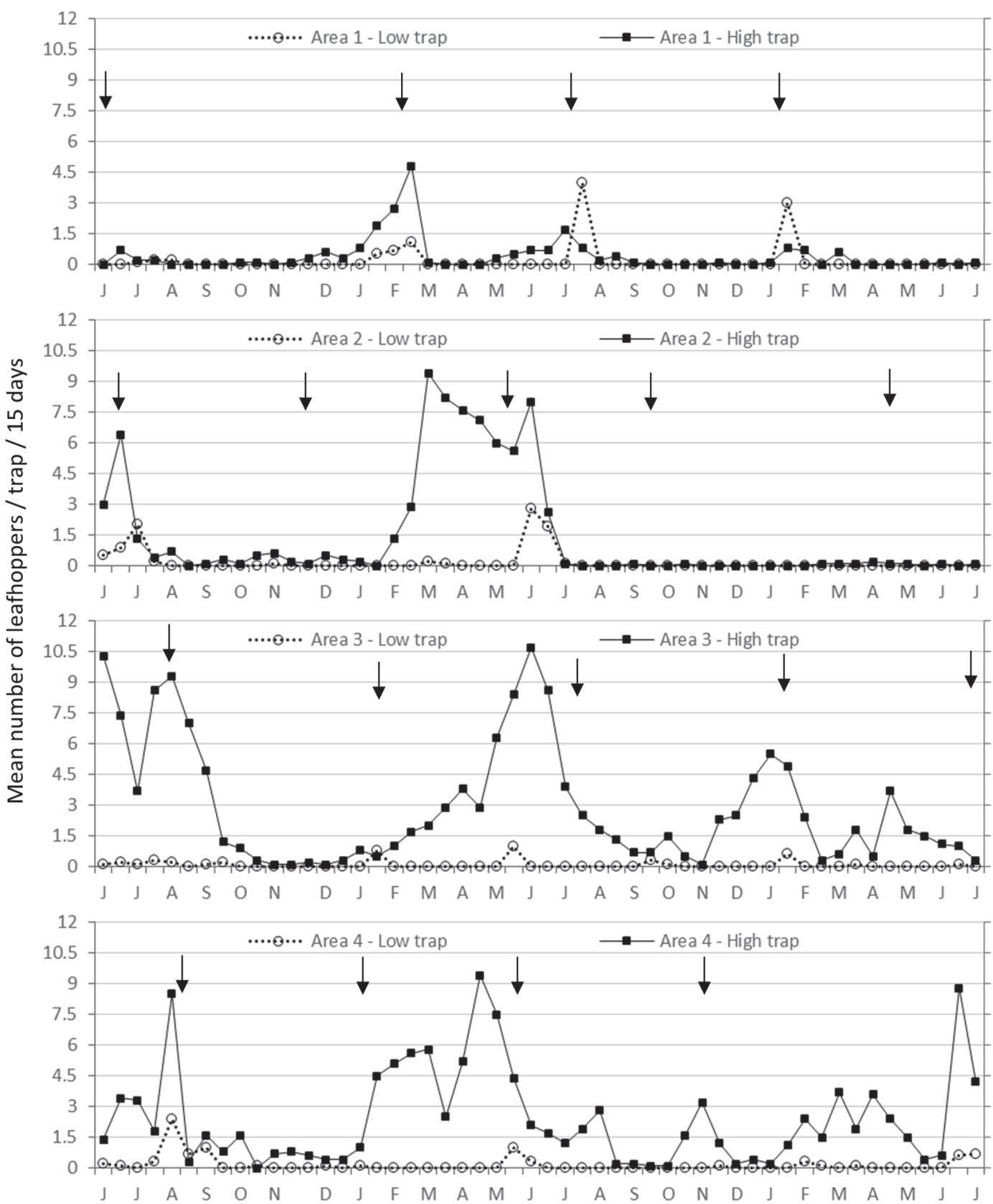

Fig. 2. Populational fluctuation of adults of Homalodisca spottii collected by yellow sticky traps placed at $45 \mathrm{~cm}$ aboveground (low trap - open circles), and $45 \mathrm{~cm}$ above the crop canopy (high trap - filled circles) in four vineyards of Vitis vinifera in Petrolina, PE (Areas 1 and 2) and Santa Maria da Boa Vista, PE (Areas 3 and 4) from June 2005 to July 2007. Arrows indicate pruning dates.

Multiple regression analyses showed no significant correlations between average temperature $\left({ }^{\circ} \mathrm{C}\right)$ and rainfall $(\mathrm{mm})$ (Fig. 3) with trap catches of adults of $H$. spottii. Despite the lack of statistical correlation with climatic factors, the largest captures of adults of $H$. spottii occurred in periods of higher rainfall, usually between November and June (Fig. 3), and population build up was apparently related to the onset of the rainy season. In 2006, the population of $H$. spottii started increasing in January (Fig. 2), 2 months after the first spring rains in November of 2005. The following rainy season began in September of 2006, 2 months earlier than in the previous year (Fig. 3), and consequently sharpshooter captures increased earlier, in October and November of 2006 (Fig. 2).

Another factor responsible for the observed capturing profile may be the availability of developing branches for the sharpshooters, which was influenced by the pruning systems adopted. In Areas 3 and 4, pruning was done gradually in different sections of the plots, so that grapes could be produced during the entire year for the market. Therefore, while some rows were pruned (without branches), others were in shoot emission phase, fruit maturation phase, and harvest phase. Consequently, all phenological phases of the crop were 


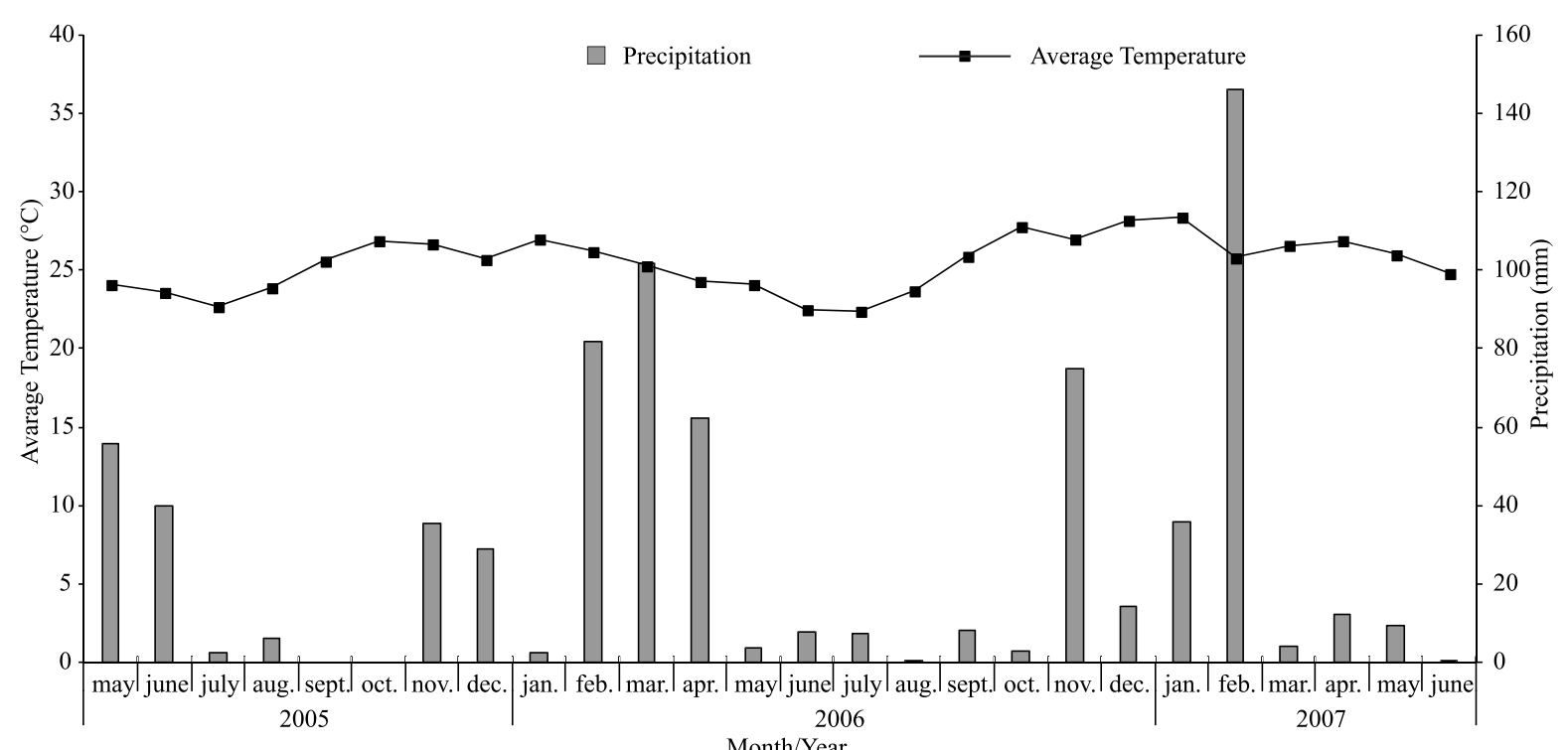

Fig. 3. Average temperature $\left({ }^{\circ} \mathrm{C}\right)$ and precipitation $(\mathrm{mm})$ at the meteorological station 1 of Bebedouro, PE, from May 2005 to June 2007.

present in Areas 3 and 4 throughout the sampling period. In this case, the availability of green branches in the grapevines for food and oviposition was constant, allowing the population to remain in the area.

In areas 1 and 2, pruning was carried out simultaneously in the entire grapevine plots (Fig. 2), with impacts on the population fluctuation of both common sharpshooter species. A decrease in sharpshooter population was recorded after each pruning in those areas, possibly because the green parts of the grapevines were eliminated in the entire plots. During this period, the presence of other plants in adjacent areas or between crop rows could offer alternative food and oviposition sources for sharpshooter species. This may be one of the reasons why higher trap catches occurred in Area 3 , which has greater vegetation diversity in the adjacent areas. Pruning also influenced adult capture at low traps; an increase in numbers was generally observed in those traps right after the pruning date, possibly because sharpshooters may switch to herbaceous hosts (Fig. 2).

In conclusion, results of this survey showed a very low diversity of potential $X$. fastidiosa vector species in vineyards of the São Francisco River Valley. Homalodisca spottii was a predominant species trapped at crop canopy level, and the only one observed engaged in feeding and reproduction activities on grapevines. Tapajosa fulvopunctata was another commonly trapped sharpshooter, but in much lower numbers and predominantly caught by traps located near the ground, suggesting a preference for herbaceous plants. Because $H$. spottii is an abundant sharpshooter that colonizes grapevines and occurs throughout the year in this crop, it could be an important vector if a $X$. fastidiosa strain pathogenic to grapevines were introduced in that region. Further research is necessary to determine the competence of these sharpshooters to transmit $X$. fastidiosa to grapevines and/or other plants, in order to confirm their potential as vectors of this pathogen.

\section{ACKNOWLEDGMENTS}

We thank Dr. Francisca Nemaura Haji, Mr. José Gualberto de Freitas, and VALEXPORT (Association of Growers and Exporters of Fruits of the São Francisco River Valley) for the logistic and financial support during this survey. The first and second authors thank National Council for Scientific and Technological Development (CNPq) for the doctoral and research fellowships, respectively. This article is part of the doctoral thesis of the first author.

\section{REFERENCES}

Almeida, R.P.P., Nascimento, F.E., Chau, J., Prado, S.S., Tsai, C.-W., Lopes, S.A. \& Lopes, J.R.S. 2008. Genetic structure and biology of Xylella fastidiosa strains causing disease in citrus and coffee in Brazil. Applied Environmental Microbiology 74: 3690-3701.

Araújo, J.P.L. 2004. Cultivo da Videira. Available at: http://sistemasde producao.cnptia.embrapa.br/FontesHTML/Uva/CultivodaVideira/ custos.htm (accessed 19 November 2012).

Azevedo Filho, W.S. \& Carvalho, G.S. 2001. Giponíneos (Hemiptera, Cicadellidae) associados à cultura de Citrus sinensis (L.) Osbeck no Rio Grande do Sul, Brasil: I - Sordana e Reticana. Biociências 9: 121-139.

Fajardo, T.V.M., Kuhn, G.B., Eiras, M. \& Nickel, O. 2002. Detecção de Closterovirus em videira e caracterização parcial de um isolado do Grapevine leafroll-associated virus 3. Fitopatologia Brasileira 27: 58-64.

French, W.J. \& Kitajima, E.W. 1978. Occurrence of plum leaf scald in Brazil and Paraguay. Plant Disease 62: 1035-1038.

Giustolin, T.A., Lopes, J.R.S., Querino, R.B., Cavichioli, R.R., Zanol, K., Azevedo Filho, W.S. \& Mendes, M.A. 2009. Diversidade de Hemiptera Auchenorrhyncha em citros, café e fragmento de floresta nativa do estado de São Paulo. Neotropical Entomology 38: 834-841.

Hickel, E.R., Ducroquet, J.-P.H.J., Leite Junior, R.P. \& Leite, R.M.V.B.C. 2001. Fauna de Homoptera: Auchenorrhyncha em pomares de ameixeira em Santa Catarina. Neotropical Entomology 30: 725-729.

IBGE [Instituto Brasileiro de Geografia e Estatística]. 2010. Banco de dados agregados. Available at: http://www.sidra.ibge.gov.br/bda (accessed 03 March 2010). 
Kuniyuki, H., Rezende, J.A.M., Gaspar, J.O. \& Yuki, V.A. 2008. Detecção do Grapevine leafroll-associated virus 5 no Estado de São Paulo. Summa Phytopathologica 34: 366-367.

Krugner, R., Lopes, M.T.V., Santos, J.S. de, Beretta, M.J.G. \& Lopes, J.R.S. 2000. Transmission efficiency of Xylella fastidiosa to citrus by sharpshooters and identification of two new vector species, p. 423. In: Graça, J.V., Lee, R.F. \& Yokomi, R.K. (eds.). Proceedings of the Fourteenth Conference of the International Organization of Citrus Virologists. Riverside, International Organization of Citrus Virologists Proceedings.

Lee, R.F., Beretta, M.J.G., Hartung, J.H., Hooker, M.E. \& Derrick, K.S. 1993. Citrus variegated chlorosis: Confirmation of a Xylella fastidiosa as the causal agent. Summa Phytopathologica 19: 123-125.

Li, W.-B., Pria, W.D., Teixeira, D.C., Miranda, V.S., Ayres, A.J., Franco, C.F., Costa, M.G., He, C.-X., Costa, P.I. \& Hartung, J.S. 2001. Coffee leaf scorch caused by a strain of Xylella fastidiosa from citrus. Plant Disease 85: 501-505.

Lima, J.E.O., Miranda, V.S., Hartung, J.S., Brlansky, R.H., Coutinho, A., Roberto, S.R. \& Carlos, E.F. 1998. Coffee leaf scorch bacterium: axenic culture, pathogeniticy, and comparison with Xylella fastidiosa of citrus. Plant Disease 82: 94-97.

Lopes, J.R.S., Müller, C., Azevedo Filho, W.S. de \& Botton, M. 2008. Faunistic analysis of sharpshooters in plum orchards of Rio Grande do Sul State, Brazil, p. 39-42. In: Proceedings, 2008 Pierce's Disease Research Symposium. Sacramento, California Department of Food and Agriculture.

Marucci, R.C., Lopes, J.R.S. \& Cavichioli, R.R. 2008. Transmission Efficiency of by Sharpshooters (Hemiptera: Cicadellidae) in Coffee and Citrus. Journal of Economic Entomology 101: 1114-1121.

Miranda, M.P., Lopes, J.R.S., Nascimento, A.S., Santos, J.L. dos \& Cavichioli, R.R. 2009. Levantamento Populacional de Cigarrinhas (Hemiptera: Cicadellidae) Associadas à Transmissão de Xylella fastidiosa em Pomares Cítricos do Litoral Norte da Bahia. Neotropical Entomology 38: 827-833.

Neroni, R.C., Bedendo, I.P. \& Kuniyuki, H. 2006. Identificação molecular de fitoplasmas associados ao amarelo da videira, p. 243. In: Fitopatologia Brasileira, vol. 31. Anais do Congresso Brasileiro de Fitopatologia, 2006, Salvador/BA. Lavras, Sociedade Brasileira de Fitopatologia.

Ott, A.P., Azevedo Filho, W.S. de, Ferrari, A. \& Carvalho, G.S. 2006. Abundância e sazonalidade de cigarrinhas (Hemiptera, Cicadellidae, Cicadellinae) em vegetação herbácea de pomar de laranja doce, no município de Montenegro, Estado do Rio Grande do Sul, Brasil. Iheringia Série Zoologia 96: 425-429.

Paradela Filho, O., Sugimori, M.H., Ribeiro, I.J.A., Garcia Junior, A., Beretta, M.J.G., Harakawa, R., Machado, M.A., Laranjeira, F.F., Rodrigues Neto, J., Beriam, L.O.S. 1997. Constatação de Xylella fastidiosa em cafeeiro no Brasil. Summa Phytopathologica 23: 46-49.

Purcell, A.H. 1980. Almond leaf scorch: leafhopper and spittlebug vectors. Journal of Economic Entomology 73: 834-838.

Purcell, A.H., Finlay, A.H. \& McLean, D.L. 1979. Pierce's disease bacterium: Mechanism of transmission by leafhopper vectors. Science 206: 839-841.

Rathé, A.A., Pilkington, L.J., Gurr, G.M., Hoddle, M.S., Daugherty, M.P., Constable, F. E., Luck, J.E., Powell, K.S., Fletcher, M.J. \& Edwards, O.R. 2012. Incursion preparedness: anticipating the arrival of an economically important plant pathogen Xylella fastidiosa Wells (Proteobacteria: Xanthomonadaceae) and the insect vector Homalodisca vitripennis (Germar) (Hemiptera: Cicadellidae) in Australia. Australian Journal of Entomology 51: 209-220.
Redak, R.A., Purcell, A.H., Lopes, J.R.S., Blua, M.J., Mizell, R.F. 3rd \& Andersen, P.C. 2004. The biology of xylem fluid-feeding insect vectors of Xylella fastidiosa and their relation to disease epidemiology. Annual Review of Entomology 49: 243-270.

Ringenberg, R., Lopes, J.R.S., Botton, M., Azevedo Filho, W.S. de \& Cavichioli, R.R. 2010. Análise faunística de cigarrinhas (Hemiptera: Cicadellidae) na cultura da videira no Rio Grande do Sul. Neotropical Entomology 39: 187-193.

Roberto, S.R., Coutinho, A., Lima, J.E.O. de, Miranda, V.S. \& Carlos, E.F. 1996. Transmissão de Xylella fastidiosa pelas cigarrinhas Dilobopterus costalimai, Acrogonia terminalis e Oncometopia facialis em citros. Fitopatologia Brasileira 21: 517-518.

SAS Institute. 2003. SAS 9.1.3 service pack3. Cary, SAS Institute.

Schaad, N.W., Postnikova, E., Lacy, G., Fatmi, M. \& Chang, C.J. 2004. Xylella fastidiosa subspecies: $X$. fastidiosa subsp. piercei, subsp. nov., X. fastidiosa subsp. multiplex subsp. nov., and $X$. fastidiosa subsp. pauca subsp. nov. Systematic and Applied Microbiology 27: 290-300.

Severin, H.H.P. 1950. Spittle-insect vectors of Pierce's disease virus II. Life history and virus transmission. Hilgardia 19: 357-382.

Silveira Neto, S., Nakano, O., Bardin, D. \& Villa Nova, N.A. 1976. Manual de ecologia dos insetos. Piracicaba, Agronômica Ceres, 419 p.

Silveira Neto, S., Parra, J.R.P., Zucchi, R.A. \& Alves, S.B. 1986. Zoneamento ecológico para as cigarrinhas-de-pastagens (Homoptera: Cercopidae) no Brasil. Anais da Sociedade Entomológica do Brasil 15: $149-159$.

Statsoft, INC. 2005. Statistica (data analysis software system), version 7.1. Available at: www.statsoft.com (accessed 17 October 2009).

Su, C.-C., Chang, C.J., Chang, C.-M., Shih, H.-T., Tzeng, K.-C., Jan, F.-J., Kao, C.-W. \& Deng, W.-L. 2013. Pierce's Disease of Grapevines in Taiwan: Isolation, Cultivation and Pathogenicity of Xylella fastidiosa. Journal of Phytopathology 161: 389-396.

Takiya, D.M., Cavichioli, R.R. \& Mckamey, S.H. 2006. Brazilian sharpshooters of the genus Homalodisca Stål, 1869 (Hemiptera, Cicadellidae): notes, new records, key to species, first description of the male of H. ignota Melichar, 1924, and a new Northeastern species. Zootaxa 1249: 23-36.

Teixeira, A.H. \& Silva, B.B. 1999. Influência do rio São Francisco no microclima de suas margens. In: Congresso Brasileiro de Agrometeorologia, 11. \& Reunião Latino-Americana de Agrometeorologia, 2., 1999, Florianópolis, SC. Anais... Florianópolis, EPAGRI/SBA. CD-ROM. Available at: http:// www.alice.cnptia.embrapa.br/handle/doc/133587 (assessed 1 January 2014).

Tsai, C.W., Rowhani, A., Golino, D.A., Daane, K.M. \& Almeida, R.P.P. 2010. Mealybug transmission of grapevine leafroll viruses: an analysis of virus-vector specificity. Phytopathology 100: 830-834.

Yamamoto, P.T. \& Gravena, S. 2000. Espécies e abundância de cigarrinhas e psilídeos (Homoptera) em pomares cítricos. Anais da Sociedade Entomológica do Brasil 29: 169-176.

Yamamoto, P.T., Roberto, S.R., Pria Júnior, W.D., Felippe, M.R., Miranda, V.S., Teixeira, D.C. \& Lopes, J.R.S. 2002. Transmissão de Xylella fastidiosa pelas cigarrinhas Homalodisca ignorata e Acrogonia virescens (Hemiptera: Cicadellidae) em plantas cítricas. Summa Phytopathologica 28: $178-181$.

Young, D.A. 1968. Taxonomic study of the Cicadellinae. Part 1, Proconiini. Bulletin of the United States National Museum 261: 1-287.

Young, D.A. 1977. Taxonomic study of the Cicadellinae (Homoptera: Cicadellidae). Part 2. New World Cicadelliini and genus Cicadella. Technical Bulletin of the North Carolina Agricultural Experiment Station 239: 1-1135.

Received 10 September 2013; 29 March 2014

Associate Editor: Daniela M. Takiya 